\title{
Seasonal photosynthetic patterns of the seagrass Thalassia testudinum in the western Gulf of Mexico
}

\author{
Sharon Z. Herzka*, Kenneth H. Dunton \\ Marine Science Institute, The University of Texas at Austin, 750 Channelview Drive, Port Aransas, Texas 78373-5015, USA
}

\begin{abstract}
Seasonal photosynthetic performance was compared between 2 distunct populations of Thalassia testudinum in Texas (USA) during an annual period. The validity of using laboratory leaf incubations to set light requirements was tested by comparison to in situ whole-plant measurements of photosynthesis versus irradiance ( $P$ vs $I)$. Cosine $(2 \pi)$ and spherical $(4 \pi)$ sensors were used to measure photon flux density (PFD) in laboratory and field experiments, respectively, In addition, differences in PFDs recorded with the different sensors were examined by completing simultaneous in situ measurements. This data was used to compare estimates of production based on numerical integration and the daily light saturation period $\left(H_{\text {sat }}\right)$. Laboratory-based seasonal photosynthetic performance was dependent on temperature and was site-specific. Rates of photosynthesis varied from ca 45 to $345 \mu \mathrm{mol} \mathrm{O}_{2}$ $g$ dry $\mathrm{wt}^{-1} \mathrm{~h}^{-1}$, while dark respiration values ranged from ca 5 to $105 \mu \mathrm{mol} \mathrm{O}_{2} \mathrm{~g}$ dry $\mathrm{wt}^{-1} \mathrm{~h}^{-1}$ Late spring and summer saturation irradiance $\left(I_{k}\right)$ values derived from laboratory incubations $\left(I_{k(2 \pi)}=85 \mu\right.$ mol photon $\left.\mathrm{m}^{-2} \mathrm{~s}^{-1}\right)$ were about 3-fold lower than in situ whole-plant measurements $\left(I_{\mathrm{k}(4 \pi)}=290 \mu \mathrm{mol}\right.$ photon $\left.\mathrm{m}^{-2} \mathrm{~s}^{-1}\right)$. Despite the large apparent differences in $I_{\mathrm{k}(2 \pi)}$ and $I_{\mathrm{k}(4 \pi)}$ values, integrated production calculated using the 2 estimations were similar because of lower in situ $2 \pi$ cosine PFD values compared to the spherical $4 \pi$ sensor (ca $50 \%$ ). However, integrated production estimates using laboratory $P$ vs $I$ data were still 12 to $22 \%$ lower than estumates based on whole-plant incubations. Application of the $H_{\text {sat }}$ model to the data showed that the predictive capacity varied as a function of water transparency, source of $P$ vs $l$ data and sensor utilized; values were 14 to $100 \%$ lower than numerically integrated production. The results underscore the value of in situ PFD and entire-plant $P$ vs $I$ measurements for seagrasses, especially under conditions of low water transparency characteristic of estuarine and near shore environments.
\end{abstract}

KEY WORDS: Seagrass $\cdot$ Thalassia testudinum Production models $\cdot$ Photosynthesis $\cdot$ PFD $\cdot H_{\text {sat }}$

\section{INTRODUCTION}

Light is a major factor controlling seagrass growth and distribution and is particularly important in establishing depth limits for growth (Buesa 1974, Wiginton \& McMillan 1979, Wetzel \& Penhale 1983, Dennison 1987, Duarte 1991). On a worldwide basis, large losses of seagrass areal coverage have been reported as a consequence of decreased light availability (Backman \& Barilotti 1976, Cambridge \& McComb 1984, Giesen et al 1990, Onuf 1994). Algal blooms caused by input of excess nutrients, resuspension of bottom sediments, dredging and increased sediment run-off have been

\footnotetext{
•E-mail: iguanas@utmsi.zo.utexas.edu
}

linked to light reduction, causing the decline of seagrass coverage and productivity (Orth \& Moore 1983, Cambridge et al. 1986, Goldsborough \& Kemp 1988, Pulich \& White 1991, Dennison et al. 1993, Onuf 1994).

Seagrass depth limits have been correlated with Secchi depth measurements (Vicente \& Rivera 1982), as well as instantaneous and continuous measurements of photon flux density (PFD, 400 to $700 \mathrm{~nm}$; Dennison \& Alberte 1985, Zimmerman et al. 1991, Dunton 1994). Seagrass minimum light requirements may also be determined by establishing the relationship between underwater PFD and photosynthetic production through the construction of photosynthesis versus irradiarce ( $P$ vs $I$ ) curves (Kenworthy \& Haunert 1991, Batuick et al. 1992, Morris \& Tomasko 1993). 
However, the application of the $P$ vs $I$ model to assess seagrass light requirements is complicated by the various methodologies and instruments used to measure PFDs and photosynthesis. A variety of mathematical models used to fit $P$ vs $I$ curves yield different values for photosynthetic parameters (Gallegos \& Platt 1981, Fourqurean \& Zieman 1991, Frenette et al. 1993, Henley 1993, Zimmerman et al. 1994). In addition, both spherical $(4 \pi)$ and cosine $(2 \pi)$ quantum sensors are used to determine PFD (Drew 1979, Dennison \& Alberte 1985, Marsh et al. 1986, Dunton \& Tomasko 1994). Since photosynthetic parameters, particularly the saturation irradiance $\left(I_{k}\right)$, are used to determine light requirements based on the daily light saturation period ( $H_{\text {sati }}$ Dennison \& Alberte 1982,1985 ), the use of the appropriate mathematical model and PFD sensor is critical

Furthermore, both laboratory and field measurements of oxygen evolution have been used io deiermine leaf photosynthetic rates (Drew 1978, Williams \& McRoy 1982, Marsh et al. 1986, Pirc 1986, Roberts \& Moriarty 1987, Pérez \& Romero 1992, Dunton \& Tomasko 1994). Laboratory photosynthctic measurements based solely on leaf tissue neglect the respiratory demands of non-photosynthetic plant material which can comprise over $80 \%$ of seagrass biomass (Caffrey \& Kemp 1991, Kraemer \& Alberte 1993, Zimmerman et al. 1995). However, few studies have incorporated the respiratory requirements of below-ground tissues in photosynthetic measurements and carbon balance models (but see Zimmerman et al. 1989, 1991. Fourqurean \& Zieman 1991, Duntan \& Tomasko 1994). Since seagrass light requirements are often derived from laboratory incubations of blade segments where PFD is measured with a cosine quantum sensor, an evaluation of the applicability of these techniques to the field is necessary.

Photosynthetic parameters can follow distinct seasonal patterns (Drew 1978, Libes 1986, Pirc 1986). Therefore, in areas where temperature and PFDs fluctuate widely during the annual cycle, seagrass light requirements may change throughout the year (Dennison 1987). Since the Coastal Bend region of the Gulf of Mexico is toward the northern limit of the range of Thalassia testudinum Banks ex König, studies characterizing the seasonal photosynthetic performance of this species reflect physiological characteristics near its temperature tolerance limit.

The objectives of this study were to examine seasonal patterns in $P$ vs $I$ parameters as related to annual fluctuations in temperature, underwater PFD and blade chlorophyll content for 2 distinct populations of Thalassia testudinum in Texas. Differences between photosynthetic parameters derived from laboratory and in situ photosynthetic measurements were exam- ined by direct comparison of $P$ vs $I$ data derived through both methods. Likewise, we studied the implications of utilizing laboratory and field-derived saturation irradiance values to determine light requirements. The adequacy of estimating production based on PFD measured with spherical and cosine sensors in conjunction with laboratory or in situ $P$ vs $I$ measurements was determined through calculation of daily production estimates based on simultaneous PFD measurements completed in situ with both sensors. In addition, the validity of using $H_{\text {sat }}$ to estimate production was examined by comparison to production values derived through numerical integration of $P$ vs $I$ curves

\section{MATERIALS AND METHODS}

Study sites. The study focused on 2 spatially isolated populations of Thalassia testudinum located at similar depths and about $200 \mathrm{~km}$ apart on the south Texas coast (USA). The northernmost population, located at East Flats on the eastern side of Corpus Christi Bay $\left(27^{\circ} 49^{\prime} \mathrm{N}, 97^{\circ} 7^{\prime} \mathrm{W}, \mathrm{CCB}\right)$, has been the subject of previous studies on the biology of $T$. testudinum (Czerny \& Dunton 1995, Lee \& Dunton 1996, 1997). The lower

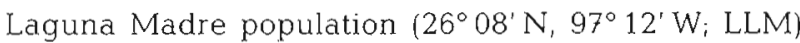
is located east of the Gulf Intracoastal Waterway (GIWW) near South Padre Island and about $15 \mathrm{~km}$ north of the Río Grande (Fig. 1)

Sampling at both stations took place between October 1994 and December 1995. Mean depths at CCB and LLM were 110 and $126 \mathrm{~cm}$, respectively. During visits to each site, water samples were collected for determinations of water column dissolved inorganic nitrogen (DIN: $\mathrm{NO}_{3}{ }^{-}+\mathrm{NO}_{2}^{-}, \mathrm{NH}_{4}{ }^{+}$) and chlorophyll a $(n=4)$. DIN and total water column chlorophyll were measured spectrophotometrically following the methods of Parsons et al. (1984). All values are reported as mean $\pm \mathrm{SE}$

Photon flux density. Continuous measurements of underwater photon flux density were collected at CCB and LLM from October 1994 to December 1995. An LI-193SA spherical quantum sensor positioned at canopy height (ca $25 \mathrm{~cm}$ above the bottom) provided input to an LI-1000 datalogger (LI-COR, Inc., Lincoln, NE, USA) encased in a waterproof underwater housing. Data were collected at 1 min intervals and integrated hourly; the setup was maintained as described in Dumton (1994). The CCB datalogger and sensor were lost in November 1995, hence no data are available after this date.

Seasonal laboratory $\boldsymbol{P}$ vs $\boldsymbol{I}$. Whole plants were collected from the CCB and LLM stations using a $15 \mathrm{~cm}$ coring device. Intact cores were placed in $20 \mathrm{l}$ buckets for transport and gently moved to 80 I aquaria upon 


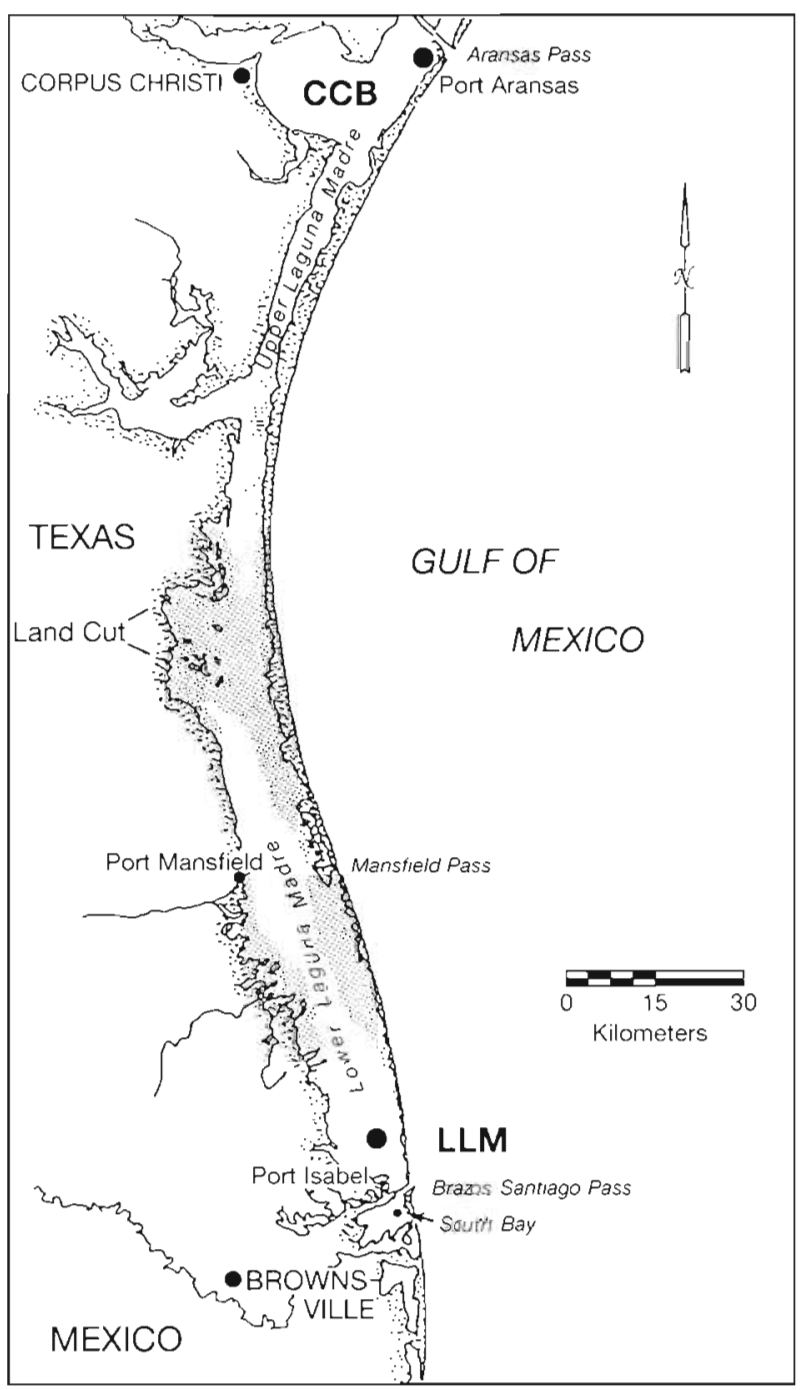

Fig. 1. Thalassia testudinum study sites in East Flats, Corpus Christi Bay (CCB) and lower Laguna Madre (LLM), Texas, USA. Stippled areas represent depths less than $1 \mathrm{~m}$

arrival at the laboratory. Plants were maintained within $\pm 2{ }^{\circ} \mathrm{C}$ of ambient temperatures under flowing seawater and irradiated with approximately $50 \mu \mathrm{mol}$ photon $\mathrm{m}^{-2} \mathrm{~s}^{-1}$ with overhead fluorescent lights on a 12:12 h light:dark regime.

$P$ vs $I$ incubations were performed at temperatures reflecting in situ conditions $\left( \pm 2^{\circ} \mathrm{C}\right)$ during 7 periods between November 1994 and December 1995. Collection dates for $P$ vs $I$ material, in situ and incubation temperatures are listed in Table 1. Experiments were completed within 5 d of collection ( $n=4$ to 7 blades per site and sampling time); site-specific measurements were made within $3 \mathrm{wk}$ of each other at the same temperature to permit comparison among stations. Although intraseasonal variation in photosynthetic performance may occur within a 3 wk period, water column temperature and light availability were not observed to change substantially between intervals. Due to technical difficulties with the oxygen electrode system, no data were collected for CCB in November 1994.

Since seagrass photosynthetic rates have been shown to vary with leaf age and position (Mazella et al. 1980), $2 \mathrm{~cm}$ blade segments were cut $2 \mathrm{~cm}$ above the bundle sheath of the second or third leaf. Blade segments were cleaned of epiphytes by gentle scraping and returned to the aquaria for a $2 \mathrm{~h}$ period to reduce wounding effects. Diel cycles in photosynthetic parameters, particularly the maximum rate of photosynthesis $\left(P_{\max }\right)$, have been documented in phytoplankton (Prézelin 1992), macroalgae (Hanelt et al. 1993) and seagrasses (Kemp et al. 1987). Preliminary data suggested Thalassia testudinum displayed a diel rhythm, therefore $P$ vs $I$ runs were completed between 07:00 and 18:00 h to attain an average for daylight hours.

Blade oxygen consumption and evolution rates were measured using a $14 \mathrm{ml}$ chamber fitted with a watertight cap, polarographic oxygen electrode, magnetic stirring mechanism and water jacket for temperature control (Rank Bros, Bottisham, England) as described by Dunton \& Tomasko (1994) and Czerny (1994). Light was provided by a tungsten halide lamp and slide projector fitted with neutral density slides (Kodak, Inc.). PFDs were measured with a flat cosine sensor (LI-192SA) inserted into the chamber directly behind the plant material. Photosynthesis was measured at 10 light levels $(0,11,21,42,100,129,200$, 370,565 and $890 \mu \mathrm{mol}$ photon $\mathrm{m}^{-2} \mathrm{~s}^{-1}$ ). Fresh filtered seawater was used for each incubation and no evidence of $\mathrm{CO}_{2}$ limitation was observed during the $2 \mathrm{~h}$ period. A 6 min stabilization period was allowed for each light level prior to data collection to avoid problems with lacunal gas storage (Dunton \& Tomasko 1994). Chamber oxygen consumption rates were not significant relative to blade photosynthesis and respiration rates. No evidence of photoinhibition was observed in laboratory or field experiments (Herzka \& Dunton unpubl. data). After completion of a run, blades were dried at $60^{\circ} \mathrm{C}$ and weighed.

Respiration and photosynthetic rates were calculated through regression analysis and normalized to dry weight of leaf tissue. The Smith-Talling function provided an adequate fit to the data $\left(\mathrm{r}^{2}>0.90\right.$; Smith 1936 , Talling 1.957):

$$
\text { Production }=P_{\max }\left(\frac{\alpha I}{\sqrt{P^{2} \max +(\alpha I)^{2}}}\right)
$$

where $P_{\max }$ is the gross maximum rate of photosynthesis calculated as net $P_{\max }+$ dark respiration $\left(R_{\mathrm{d}}\right)$. The maximum rate of photosynthesis is reported on a per 
Table 1. Dates of collection, in situ and incubation temperature and chlorophyll content of Thalassia testudinum blades from lower Laguna Madre (LLM) and Corpus Christi Bay (CCB) used in laboratory $P$ vs $I$ experiments. Blade chlorophyll values represent mean $\pm \mathrm{SE}_{\text {; }}$ gdw: $g$ dry $w t$; nd: no data

\begin{tabular}{|c|c|c|c|c|c|c|}
\hline Station & Period & $\begin{array}{l}\text { Collection } \\
\text { date }\end{array}$ & $\begin{array}{l}\text { Temp } \\
\text { In situ }\end{array}$ & $\begin{array}{l}\left({ }^{\circ} \mathrm{C}\right) \\
\mathrm{Lab} .\end{array}$ & $\begin{array}{l}\text { Blade chlor } \\
\mathrm{mg} \text { chl } a, b \mathrm{gdw}{ }^{-}\end{array}$ & $\begin{array}{l}\text { ophyll } \\
\text { chl } a: b\end{array}$ \\
\hline LLM & 1 & 21 Nov 1994 & 25 & 24 & nd & nd \\
\hline $\begin{array}{l}\text { LLM } \\
\text { CCB }\end{array}$ & 2 & $\begin{array}{l}2 \text { Feb } 1995 \\
24 \text { Jan } 1995\end{array}$ & $\begin{array}{l}17 \\
16\end{array}$ & $\begin{array}{l}15 \\
15\end{array}$ & $\begin{array}{l}7.36 \pm 0.86 \\
6.29 \pm 0.37\end{array}$ & $\begin{array}{l}2.91 \pm 0.04 \\
2.78 \pm 0.03\end{array}$ \\
\hline $\begin{array}{l}\text { LLM } \\
\text { CCB }\end{array}$ & 3 & $\begin{array}{l}12 \text { Apr } 1995 \\
17 \text { Apr } 1995\end{array}$ & $\begin{array}{l}25 \\
27\end{array}$ & $\begin{array}{l}25 \\
25\end{array}$ & $\begin{array}{l}5.30 \pm 0.25 \\
6.54 \pm 0.42\end{array}$ & $\begin{array}{l}2.92 \pm 0.06 \\
2.64 \pm 0.14\end{array}$ \\
\hline $\begin{array}{l}\text { LLM } \\
\text { CCB }\end{array}$ & 4 & $\begin{array}{r}2 \text { Jul } 1995 \\
15 \text { Jun } 1995\end{array}$ & $\begin{array}{l}30 \\
28\end{array}$ & $\begin{array}{l}28 \\
28\end{array}$ & $\begin{array}{l}3.90 \pm 0.34 \\
4.99 \pm 0.19\end{array}$ & $\begin{array}{l}2.85 \pm 0.09 \\
2.47 \pm 0.05\end{array}$ \\
\hline $\begin{array}{l}\text { LLM } \\
\text { CCB }\end{array}$ & 5 & $\begin{array}{l}27 \text { Jul } 1995 \\
2 \text { Aug } 1995\end{array}$ & $\begin{array}{l}31 \\
30\end{array}$ & $\begin{array}{l}31 \\
31\end{array}$ & $\begin{array}{l}3.92 \pm 0.12 \\
4.13 \pm 0.35\end{array}$ & $\begin{array}{l}2.75 \pm 0.08 \\
2.48 \pm 0.06\end{array}$ \\
\hline $\begin{array}{l}\text { LLM } \\
\text { CCB }\end{array}$ & 6 & $\begin{array}{r}27 \text { Oct } 1995 \\
9 \text { Oct } 1995\end{array}$ & $\begin{array}{l}26 \\
26\end{array}$ & $\begin{array}{l}25 \\
25\end{array}$ & $\begin{array}{l}6.29 \pm 0.42 \\
7.98 \pm 1.14\end{array}$ & $\begin{array}{l}2.79 \pm 0.06 \\
3.00 \pm 0.09\end{array}$ \\
\hline $\begin{array}{l}\text { LLM } \\
\text { CCB }\end{array}$ & 7 & $\begin{array}{r}13 \text { Dec } 1995 \\
4 \text { Dec } 1995\end{array}$ & $\begin{array}{l}18 \\
21\end{array}$ & $\begin{array}{l}20 \\
20\end{array}$ & $\begin{array}{l}5.29 \pm 0.39 \\
4.56 \pm 0.27\end{array}$ & $\begin{array}{l}2.65 \pm 0.03 \\
3.18 \pm 0.09\end{array}$ \\
\hline
\end{tabular}

to 10 per light level). Underwater pumps ran for 1 min during each 5 min period to provide circulation within the chambers. All instruments were controlled from aboard the research vessel RV 'Etta Armstrong'.

Chamber respiration was measured between 03:00 and 06:00 h for 2 or 3 nights. In addition, dark respiration $\left(R_{\mathrm{d}}\right)$ measurements of photosynthetic (green leaf tissue; PS) and non-photosynthetic tissue (sheath, short stem rhizome, and roots; NPS) were completed during the night using additional chambers and probes. Whole plant samples were collected, sieved and sorted into PS and NPS tissue at least $5 \mathrm{~h}$ prior to incubations. Sealed chambers were placed in the water column to maintain ambient temperatures ( $\mathrm{n}=2$ or 3 ).

gram dry weight and per mg chlorophyll $(a, b)$ basis (umol O $\mathrm{O}_{2} \mathrm{~g}$ dry $\mathrm{wt}^{-1} \mathrm{~h}^{-1}$ and $\mu \mathrm{mol} \mathrm{O}_{2} \mathrm{mg} \mathrm{chl}^{-1} \mathrm{~h}^{-1}$, respectively). I represents photon flux density ( $\mu \mathrm{mol}$ photon $\mathrm{m}^{-2} \mathrm{~s}^{-1}$ ) and $\alpha$ is the relative quantum yield of photosynthesis depicted by the linear slope of the light-limited region of the $P$ vs $I$ relationship [ $\mu \mathrm{mol} \mathrm{O}_{2}$ $\mathrm{mg} \mathrm{chl}^{-1} \mathrm{~h}^{-1}$ (umol photon $\left.\mathrm{m}^{-2} \mathrm{~s}^{-1}\right)^{-1}$ ). Saturation and compensation irradiances $\left(I_{\mathrm{k}}\right.$ and $\left.I_{\mathrm{c}}\right)$ were calculated as $P_{\max } / \alpha$ and $R_{\mathrm{d}} / \alpha$, respectively.

Blade chlorophyll content was determined using blade tissue from the same position on a leaf as that used for photosynthetic measurements $(n=6)$. Extractions were completed in N,N-dimethyl-formamide (DMF) and processed as described by Lee \& Dunton (1997) using the equations of Porra et al. (1989). Blade chlorophyll $(a, b)$ content and $c h l a: b$ ratios are presented in Table 1.

In situ $\boldsymbol{P}$ vs $\boldsymbol{I}$. Whole-plant $P$ vs $I$ measurements were conducted in May and September 1995 at LLM. The LLM station was selected for in situ measurements because Thalassia testudinum blades contain little epiphyte cover and water column chlorophyll concentrations were low during incubation periods.

Four 51 acrylic plastic chambers fitted with circulating pumps were placed in the monospecific Thalassia testudinum bed following the procedure of Dunton \& Tomasko (1994). PFDs were measured with a spherical quantum sensor placed at canopy level; previous data indicated that shading due to chambers is minimal (Dunton unpubl. data). Oxygen within the sealed chambers was measured using an Endeco/YSI Type 1125 Pulsed Dissolved Oxygen system similar to Dunton \& Tomasko (1994). PFD and dissolved oxygen ( $\mu \mathrm{M})$ were measured simultaneously at 5 min intervals $(n=4$
Chamber oxygen consumption rates were normalized to $1 \mathrm{~g}$ dry wt of photosynthetic tissuc ( $\mathrm{mmol} \mathrm{O}_{2} \mathrm{~g}$ dry wt leaf ${ }^{-1} \mathrm{~h}^{-1}$ ); respiration rates reflect the whole plant respiratory requirements supported by $1 \mathrm{~g}$ dry wt of photosynthetic tissue. Additionally, respiration rates of PS and NPS tissue were calculated and whole-plant respiratory demand ( $\mu$ mol $\mathrm{O}_{2} \mathrm{~g}$ dry wt leaf ${ }^{-1} \mathrm{~h}^{-1}$ ) was estimated based on NPS:PS biomass ratios derived from four $15 \mathrm{~cm}$ cores sorted and dried as described above. Whole-plant respiration based on PS and NPS respiration rates was compared to total chamber respiration estimates to determine the potential extent of other sources of benthic (i.e. non-seagrass) respiration within the chambers. Water-column respiration was measured with additional capped chambers and found to be negligible in comparison to seagrass oxygen consumption rates ( $\mathrm{n}=2$ to 4 ).

A total of 12 light levels ranging from 0 to $594 \mu \mathrm{mol}$ photon $\mathrm{m}^{-2} \mathrm{~s}^{-1}$ were used for both May and September $P$ vs I curves. For each chamber, measurements of dark oxygen consumption were added to net oxygen evolution to calculate gross production. Because of the variability of field incubations (e.g. Dunton \& Tomasko 1994), gross $P_{\text {max }}$ was calculated as the mean of the light- saturated photosynthetic rates for all chambers ( $\mathrm{n}=3$ May, $\mathrm{n}=4$ September). The relative quantum yield, $\alpha$, was calculated through regression analysis of the light-limited $\left(<215 \mu \mathrm{mol}\right.$ photon $\left.\mathrm{m}^{-2} \mathrm{~s}^{-1}\right)$ PFD levels ( $\mathrm{n}=4$ May, $\mathrm{n}=5$ September). Saturation and compensation irradiances were derived as in laboratory $P$ vs $I$ calculations. Since the photosynthetic parameters for one of the chambers during the incubations in May were unrealistic (e.g. high saturation irradiance and very low relative quantum yield), the remaining 3 chambers were used in all calculations. 
Comparison of PFD measurements with spherical and cosine sensors. A setup consisting of a spherical quantum sensor and 2 flat cosine sensors was deployed at CCB for a 10 d period in February 1996. The 2 cosine sensors were positioned $50 \mathrm{~cm}$ apart facing the vertically oriented blade surfaces and each other to resemble the orientation of Thalassia testudinum blades in the water column. PFD measurements made with the 2 cosine sensors were summed to reflect light availability to both sides of a blade and for comparison with the spherical quantum sensor. All sensors were positioned at canopy height (ca $25 \mathrm{~cm}$ ) and provided simultaneous input to a datalogger that integrated data hourly.

Modeling integrated production. Estimates of daily integrated production based on in situ and laboratoryderived $P$ vs $I$ curves and continuous measurements of underwater PFD require model functions to integrate production through time. The Smith-Talling function used to describe laboratory data, as well as the hyperbolic tangent function of Jassby \& Platt (1976), did not provided a good fit to the data due to the intrinsic convexity of the light saturation region (data not shown). In order to adequately fit the data, gross $P_{\text {max }}$ and $\alpha$ were input into the Bannister (1979) function recommended by Henley (1993):

$$
\text { Production }=P_{\max } \frac{\alpha I}{\left(P_{\max }^{c}+\left(\alpha I^{c}\right)^{1 / c}\right)}
$$

where the value of $c$ controls the convexity of the light saturation region of the $P$ vs $I$ curve. As $c \rightarrow \infty$ Bannister's function resolves into the Blackman bilinear function, while $c \rightarrow 1$ results in a rectangular hyperbola (Henley 1993). Values of $c$ for May and September were determined through analysis of residuals calculated as the difference between chamber measurements and model predictions of photosynthetic rates for the same PFD ( $c=4$ for May, $c=8$ for September). Although the Smith-Talling function (Smith 1936) is equivalent to the Bannister (1979) model when $c=2$, as mentioned previously it did not provide a good fit in the convex region of the $P$ vs $I$ field data

For comparison of production estimates using both sensor types, PFD measurements during the $10 \mathrm{~d}$ period were assumed to be representative of the typical light regime found in a seagrass bed. Laboratory $P$ vs $I$ curves were based on incident PFD on one side of the blade; transmittance through blade tissue was measured several times during the course of laboratory incubations and averaged ca $25 \%$. Therefore, one-half the sum of PFDs measured with the 2 cosine sensors (cosine (avgi) $_{1}$ ) was calculated to reflect the average incident light on one side of a blade. Production estimates ( $\mathrm{g} \mathrm{C}$ dry wt leaf $\mathrm{f}^{-1} \mathrm{~d}^{-1}$ ) derived from cosine sensor PFD measurements were all based on cosine avc $\}_{\text {. }}$. Gross integrated daily production and $H_{\text {sat }}$ production
$\left(P_{\max } \times\right.$ daily light saturation period; Dennison \& $\mathrm{Al}-$ berte 1982,1985$)$ were calculated using (1) in situ $P$ vs $I$ data from September 1995 and PFD measured with the spherical sensor, (2) in situ $P$ vs $I$ data and cosine (avg), $_{\text {, }}$ (3) the laboratory $P$ vs I curve for August combined with $\operatorname{cosine} e_{(a v g)}$ and (4) the laboratory $P$ vs $I$ curve and PFD measurements made with the spherical sensor Comparison of production estimates derived through the 4 combinations of $P$ vs $I$ data and sensors represents all possible methods used to calculate production. Production on a carbon basis was calculated using a photosynthetic quotient of unity.

Statistical analysis. Two-way analysis of variance (ANOVA) was applied to the seasonal laboratory $P$ vs $I$ data. Each photosynthetic parameter was treated as a dependent variable with sampling time and site as independent variables. Significance for all tests was set at the $p<0.05$ level. Levene's test of homogeneity of variance and the Shapiro-Wilks test of normality were used to test ANOVA assumptions (Snedecor \& Cochran 1989). Data for laboratory-derived seasonal saturation irradiances $\left(I_{k}\right)$ were square-root transformed to comply with the homogeneity of variance assumption.

Comparison of field and laboratory-collected photosynthetic parameters were completed using an independent Student's t-test. In situ data for May 1995 were compared with laboratory results from plants collected $5 \mathrm{wk}$ later in early July; incubation and field temperatures were $28^{\circ} \mathrm{C}$ (Table 1, period 4). EarlySeptember in situ $P$ vs $I$ measurements were compared with laboratory results from early August at a temperature of $31^{\circ} \mathrm{C}$ (Table 1, period 5). Due to logistical constraints, approximately $5 \mathrm{wk}$ elapsed between laboratory and field measurements; however water column temperature remained constant. When necessary, data were log-transformed to meet the assumptions of equal variance and normality.

\section{RESULTS}

\section{Water column chemistry}

Water column nitrate plus nitrite averaged $0.9 \pm 0.1$ and $1.1 \pm 0.2 \mu \mathrm{M}$ for CCB and LLM, respectively, while water column ammonium values were $1.3 \pm 0.2$ and $1.5 \pm 0.2 \mu \mathrm{M}$ (Table 2). Water column chlorophyll concentrations were low during most of the annual period, particularly during in situ $P$ vs $I$ incubations at LLM. However, a pelagophyte bloom (brown tide) abundant in the central and northern areas of the Laguna Madre (Stockwell et al. 1993) was found at the LLM station strictly during winter periods. Average water column chlorophyll a concentrations in the absence of brown tide were $6.2=0.2$ and $1.2 \pm 0.5 \mathrm{~g} \mathrm{l}^{-1}$ at CCB and LLM, 
Table 2. Physical and water column characteristics at the lower Laguna Madre and Corpus Christi Bay stations during September 1994 through December 1995 $(\mathrm{n}=18$ to 22$)$. Mean values reported; minimum and maximum values within parentheses. A Student's $t$-test was used to test for significant differences in measurements of DIN and chlorophyll a content between stations; same letters indicate no significant difference between sites $(p=0.05)$

\begin{tabular}{|ccccccc|}
\hline Site & $\begin{array}{c}\text { Temp. } \\
\left({ }^{\circ} \mathrm{C}\right)\end{array}$ & $\begin{array}{c}\text { Salinity } \\
(\%)\end{array}$ & $\begin{array}{c}\text { Depth } \\
(\mathrm{cm})\end{array}$ & $\begin{array}{c}\mathrm{NO}_{3}{ }^{-}+\mathrm{NO}_{2}{ }^{-} \\
(\mu \mathrm{M})\end{array}$ & $\begin{array}{c}\mathrm{NH}_{4}{ }^{+} \\
(\mu \mathrm{M})\end{array}$ & $\begin{array}{c}\mathrm{Chla} \\
\left(\mu \mathrm{g} \mathrm{l}^{-1}\right)\end{array}$ \\
\hline $\mathrm{CCB}$ & 25 & 31 & 110 & $0.9^{\mathrm{d}}$ & $1.3^{\mathrm{d}}$ & $6.2^{\mathrm{a}}$ \\
& $(9-33)$ & $(25-35)$ & $(65-1.35)$ & $(0.2-1.4)$ & $(0.3-4.2)$ & $(2.1-14.5)$ \\
LLM & 25 & 32 & 126 & $1.1^{\mathrm{a}}$ & $1.5^{\mathrm{a}}$ & $1.2^{\mathrm{b}}$ \\
& $(10-32)$ & $(24-37)$ & $(100-150)$ & $(0.2-4.6)$ & $(0.4-4.9)$ & $(0.3-4.7)$ \\
\hline
\end{tabular}

respectively. Chlorophyll a concentrations during the brown tide winter bloom at LLM ranged between 10 and $40 \mu \mathrm{g} \mathrm{l}^{-1}$. Average temperature, salinity and depth as well as annual minimum and maximum values are reported in Table 2.

\section{Photon flux density}

Annual integrated PFD was greater at LLM than CCB. For the period between October 1994 and September 1995, 5800 and $4500 \mathrm{~mol}$ photon $\mathrm{m}^{-2}$ were received at $L L M$ and $C C B$, respectively. Daily integrated PFD displayed a distinct seasonal pattern at LLM, accentuated by decreased light availability in winter due to the presence of the brown tide algal bloom (Fig. 2). Average daily winter values at LLM ranged between 4 and $10 \mathrm{~mol}$ photon $\mathrm{m}^{-2}$, followed by increasing underwater PFDs during the spring and an annual peak in July at $27 \mathrm{~mol}$ photon $\mathrm{m}^{-2}$. In June, mats of drift algae that frequently traverse the sea bed covered the canopy and spherical sensor at the LLM station during a 2 wk period, decreasing average daily light availability to $12 \mathrm{~mol}$ photon $\mathrm{m}^{-2}$ for that month. Underwater PFD at CCB displayed little seasonal variation and exhibited a smaller annual range than at LLM. Average daily integrated PFD was approximately $10 \mathrm{~mol}$ photon $\mathrm{m}^{-2}$ in winter; highest values occurred in February and July at about $17 \mathrm{~mol}$ photon $\mathrm{m}^{-2}$

\section{Laboratory $P$ vs $I$}

Gross $P_{\max }$ of Thalassia testudinum on a dry weight basis followed a clear seasonal pattern at both stations (Fig. 3a). Maximum photosynthetic rates were high during the early spring and summer months, followed by lower rates coincident with decreasing fall temperatures and very low metabolic activity during winter $\left(<18^{\circ} \mathrm{C}\right) . P_{\max }$ at both stations was approximately 5 - to 6 -fold higher in the early spring and summer than in winter, with annual maxima of $272.5 \pm$ $24.8 \mu \mathrm{mol} \mathrm{O}_{2} \mathrm{~g}$ dry $\mathrm{wt}^{-1} \mathrm{~h}^{-1}$ at $\mathrm{CCB}$ in June and $324.6 \pm 24.0 \mu \mathrm{mol} \mathrm{O}_{2} \mathrm{~g}$ dry $w^{-1} \mathrm{~h}^{-1}$ at LLM in April. Lowest values of $P_{\max }$, recorded at an incubation temperature of $15^{\circ} \mathrm{C}$ during winter, were $44.3 \pm 5.4$ and $58.0 \pm 3.3 \mu \mathrm{mol} \mathrm{O} 2$ $g$ dry $w^{-1} h^{-1}$ for LLM and CCB, respectively.

Maximum rates of photosynthesis based on chlorophyll content ( $\left.P_{\max (c h l)}\right)$ displayed a similar seasonal trend (not shown). At both stations, winter $P_{\text {maxichl) }}$ ranged between 6.0 and $9.2 \mu \mathrm{mol} \mathrm{O}_{2}$ mg $\mathrm{chl}^{-1} \mathrm{~h}^{-1}$, while summer minimum and maximum values were 31.5 and $65.5 \mu \mathrm{mol} \mathrm{O}_{2} \mathrm{mg} \mathrm{chl}^{-1} \mathrm{~h}^{-1}$ recorded in April and August, respectively at the CCB station. On a per $\mathrm{cm}^{2}$ basis, using a conversion factor of $0.005 \mathrm{~g}$ dry wt $\mathrm{cm}^{-2}$ ( $\mathrm{n}=20$ for both stations during different periods), the maximum rate of photosynthesis ranged between 0.22 and $0.29 \mu \mathrm{mol} \mathrm{O}_{2} \mathrm{~cm}^{-2} \mathrm{~h}^{-1}$ in winter and 1.37 and $1.63 \mu \mathrm{mol} \mathrm{O}_{2} \mathrm{~cm}^{-2} \mathrm{~h}^{-1}$ in summer.

Dark respiration followed a seasonal pattern simular to gross $P_{\max }$ (Fig. 3b), with a significant Site by Time interaction ( $p=0.048$; Table 3 ). Winter rates in February at $15^{\circ} \mathrm{C}$ were very low $(5.3 \pm 0.7$ and $12.0 \pm 2.4 \mu \mathrm{mol}$ $\mathrm{O}_{2} \mathrm{~g}$ dry $\mathrm{wt}^{-1} \mathrm{~h}^{-1}$ for LLM and CCB, respectively). Dark respiration rates followed in situ temperature trends during the year, with the highest annual value observed at the CCB station in August $1105.6 \pm 8.8 \mu \mathrm{mol}$ $\mathrm{O}_{2} \mathrm{~g}$ dry $\mathrm{wt}^{-1} \mathrm{~h}^{-1}$ ) at a temperature of $31^{\circ} \mathrm{C}$. In summer

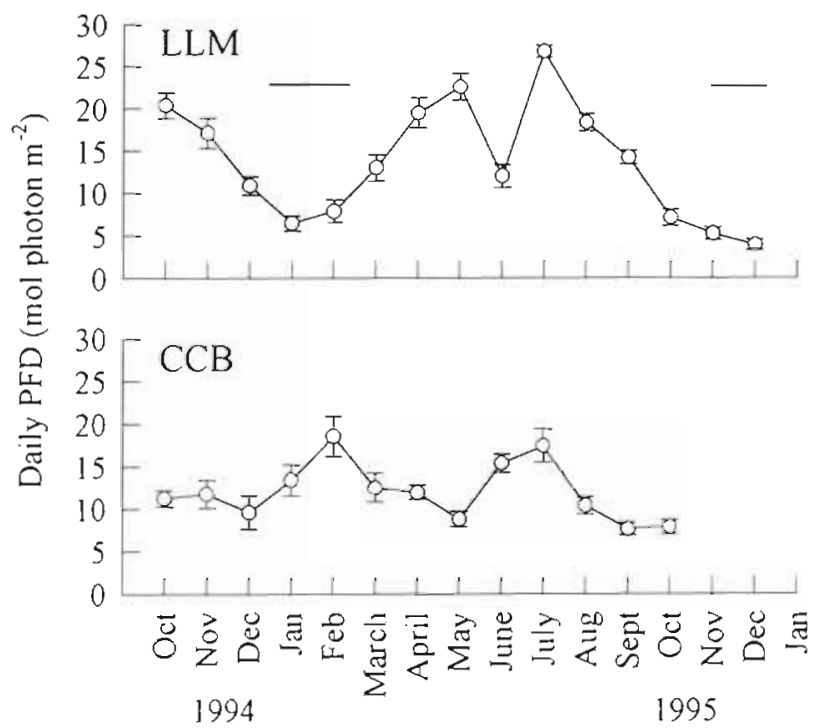

Fig. 2. Average daily integrated underwater PFD at LLM and CCB during the study period. Mean values and standard errors were calculated on a monthly basis. Horizontal lines represent periods during which an algal pelagophyte bloom

(brown tide) was intermittently seen at the LLM station 

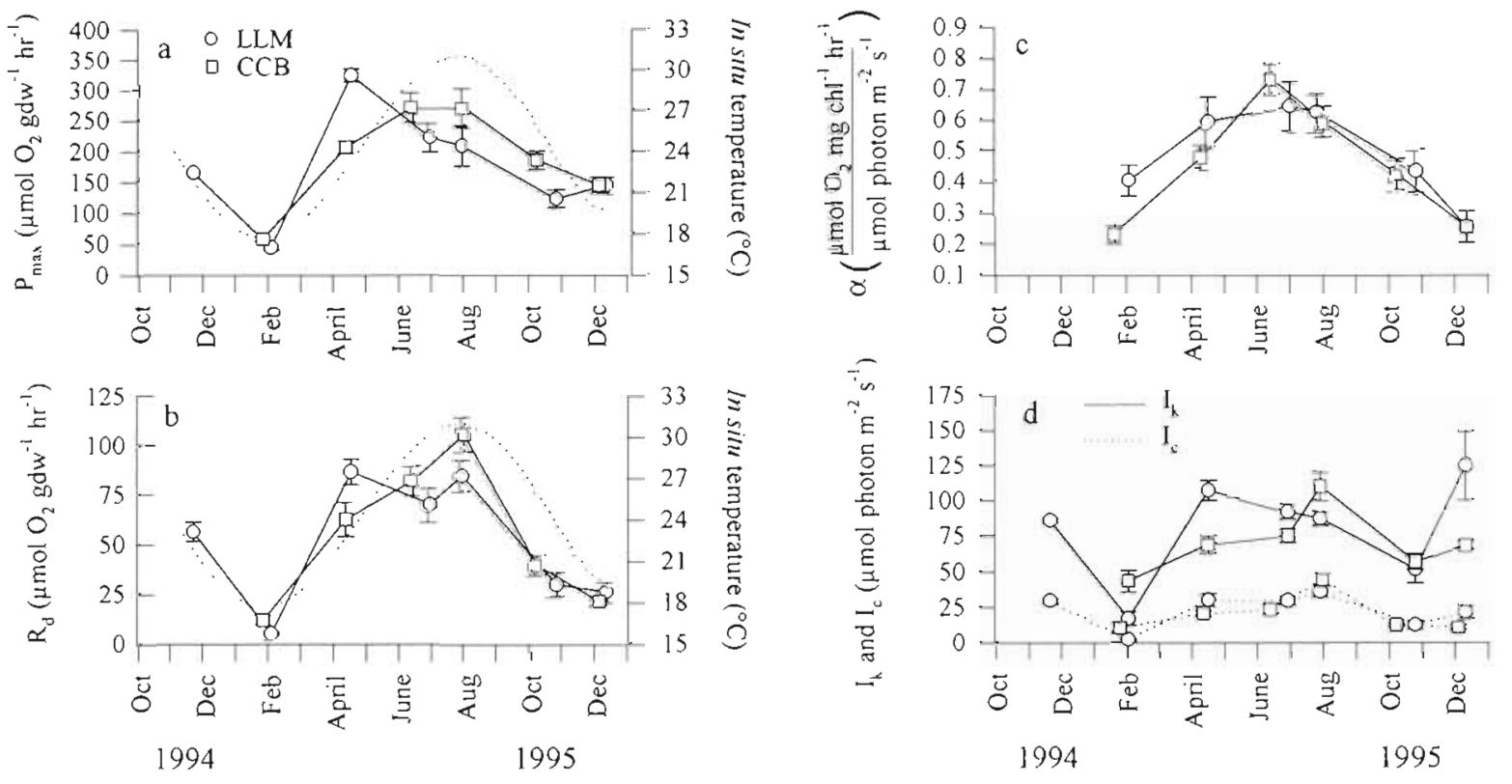

Fig. 3. Thalassia testudinum. (a) Gross maximum photosynthetic rate, (b) dark respiration, (c) relative quantum yield, and (d) saturation and compensation irradiances, derived from laboratory incubations of blade material during the study period. Dotted lines indicate approximate in situ temperature during the year as derived from non-linear regression of average daily measurements collected at 6 min intervals at a sampling platform located approximately $4 \mathrm{~km}$ from the LLM site. Values represent means $\pm \mathrm{SE}(\mathrm{n}=4$ to 6$)$

30 to $40 \%$ of gross $P_{\max }$ was consumed by dark respiration, not counting nocturnal respiration. During the winter and fall periods of low metabolic activity dark respiration accounted for 10 to $25 \%$ of $P_{\max }$.

Regression analyses of $P_{\text {max }}$ and $R_{d}$ versus temperature indicated that although the majority of the variability for both parameters was explained by temperature, respiration rates were determined by temperature to a greater extent $\left(\mathrm{r}^{2}=0.80\right.$ and 0.64 for $R_{\mathrm{d}}$ and $P_{\max }$ respectively).

Relative quantum yield on a chlorophyll $(a, b)$ basis displayed lowest values in winter, followed by increasing $\alpha$ throughout the spring and summer (Fig. 3c). In February, relative quantum yields were $0.23 \pm 0.03$ and $0.40 \pm$ $0.05 \mu \mathrm{mol} \mathrm{O}_{2} \mathrm{mg} \mathrm{chl}^{-1} \mathrm{~h}^{-1}$ ( $\mu \mathrm{mol}$ photon $\mathrm{m}^{-2} \mathrm{~s}^{-1} \mathrm{j}^{-1}$ at CCB and LLM, respectively. Peak values were recorded in mid summer (June/July), when $\alpha$ was $0.64 \pm$ 0.08 and $0.73 \pm 0.05 \mu \mathrm{mol} \mathrm{O}_{2} \mathrm{mg}$ $\mathrm{chl}^{-1} \mathrm{~h}^{-1}$ ( $\mu$ mol photon $\left.\mathrm{m}^{-2} \mathrm{~s}^{-1}\right)^{-1}$ for LLM and $\mathrm{CCB}$, respectively. Estimates of $\alpha$ decreased in late summer through early winter, approximating winter lows in December 1995. Statistical analysis indicated a correlation between $P_{\text {maxichll }}$ and $\alpha\left(r^{2}=0.62 ; \alpha=0.0064 P_{\max (c h)\}}\right.$ $+0.24)$.
Saturation and leaf compensation irradiances reflected seasonal trends in other photosynthetic parameters (Fig. 3d). Values were higher in the early spring and summer months than during fall and winter, with the exception of abnormally high $I_{k}$ values at the LLM station during December 1995 and November 1994 attributed to unusually low values of relative quantum

Table 3. ANOVA table for laboratory $P$ vs $I$ parameters with site and time as independent variables

\begin{tabular}{|llrrrrr|}
\hline & Source & SS & df & MS & F-ratio & p-value \\
\hline$P_{\max }$ & Site & 36230 & 1 & 36230 & 1.8 & 0.188 \\
& Time & 298726 & 5 & 59745 & 29.3 & 0.000 \\
& Site $\times$ Time & 65796 & 5 & 13159 & 6.5 & 0.000 \\
& Error & 95646 & 47 & 2035 & & \\
Respiration & Site & 355 & 1 & 355 & 1.5 & 0.220 \\
& Time & 56896 & 5 & 11379 & 49.4 & 0.000 \\
& Site $\times$ Time & 2810 & 5 & 562 & 2.4 & 0.048 \\
& Error & 10824 & 47 & 230 & & \\
$\alpha$ & Site & 0.001 & 1 & 0.001 & 0.061 & 0.806 \\
& Time & 0.949 & 5 & 0.190 & 11.500 & 0.000 \\
& Site $\times$ Time & 0.208 & 5 & 0.042 & 2.508 & 0.043 \\
& Error & 0.779 & 47 & 0.017 & & \\
$I_{k}$ (square-root & Site & 0.7 & 1 & 0.7 & 0.5 & 0.466 \\
transformed) & Time & 149.2 & 5 & 29.8 & 24.0 & 0.000 \\
& Site $\times$ Time & 51.8 & 5 & 10.4 & 8.3 & 0.000 \\
& Error & 58.5 & 47 & 1.2 & & \\
$I_{5} \quad$ Site & 24.2 & 1 & 24.2 & 0.5 & 0.502 \\
& Time & 7133.8 & 5 & 1426.8 & 27.0 & 0.000 \\
& Site $\times$ Time & 843.5 & 5 & 168.7 & 3.2 & 0.015 \\
& Error & 2483.5 & 47 & 52.8 & & \\
\hline
\end{tabular}




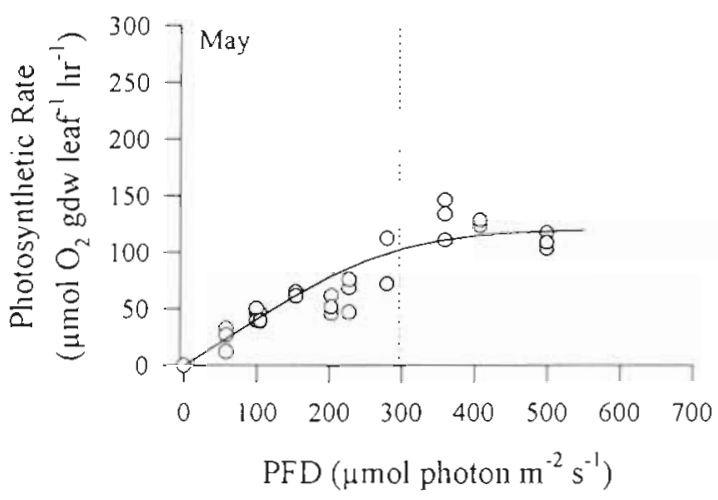

yield. Winter and fall estimates of $I_{k}$ for both stations ranged between 17 and $69 \mathrm{\mu mol}$ photon $\mathrm{m}^{-2} \mathrm{~s}^{-1}$. Peak $I_{\mathrm{k}}$ values were 107 at LLM in April and $110 \mu \mathrm{mol}$ photon $\mathrm{m}^{-2} \mathrm{~s}^{-1}$ at CCB in August. The compensation irradiance ranged from 2 and $8 \mu \mathrm{mol}$ photon $\mathrm{m}^{-2} \mathrm{~s}^{-1}$ in winter to annual maxima of 44 and $36 \mu$ mol photon $\mathrm{m}^{2} \mathrm{~s}^{1}$ in August, for CCB and LLM respectively.
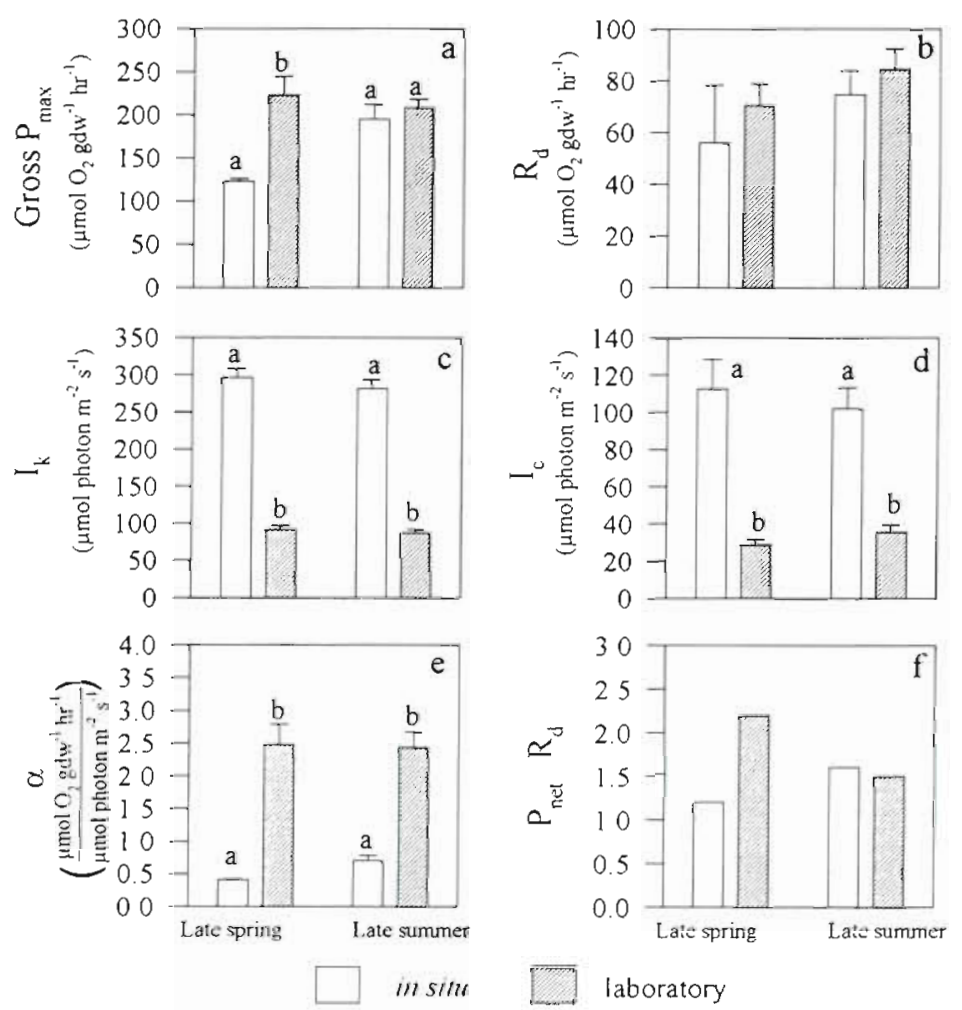

Fig. 5. Thalassia testudinum. Companson of laboratory and field-derived photosynthetic parameters for the LLM station. In situ data for May 1995 was compared with laboratory data collected 5 wk later in early July; incubation and field temperatures were $28^{\circ} \mathrm{C}$. September in situ $P$ vs $I$ measurements were compared with laboratory results from August at a temperature of $31^{\circ} \mathrm{C}$ (Table 1). Letters represent presence or absence of significant differences between methods within a study period as determined with a Student's $t$-test $(p=0.05)$. Statistical analysis was not deemed appropriate for estimates of $R_{d}$ because whole-plant estimates are based on average PS and NPS dark respiration rates corrected for root to shoot ratios (Table 4), and the source of variation is not equivalent
Two-way ANOVA indicated a significant Time by Site interaction for $P_{\max }, R_{\mathrm{d}}, \alpha, I_{\mathrm{k}}$ and $I_{\mathrm{c}}$ (Table 3 ), indicating the magnitude of changes in maximum rates of photosynthesis were not consistent over time at the 2 stations. Values of $P_{\max }, R_{\mathrm{d}}$ and $I_{\mathrm{k}}$ for the LLM population peaked in the eariy spring (Áprii), while the same photosynthetic parameters for the $\mathrm{CCB}$ population reached an annual maximum during summer months (July to August). Hence, there appeared to be approximately a 2 mo lag period in seasonal maxima of $P_{\max }, R_{\mathrm{d}}$ and $I_{\mathrm{k}}$.

\section{In situ $P$ vs $I$}

Photosynthetic parameters derived from whole-plant incubations displayed similar values in May and September, with the exception of gross $P_{\max }$, which averaged $122 \pm$ $4 \mu \mathrm{mol} \mathrm{O} \mathrm{O}_{2}$ dry wt leaf ${ }^{-1} \mathrm{~h}^{-1}$ at $28^{\circ} \mathrm{C}$ in May and $195 \pm 17 \mu \mathrm{mol} \mathrm{O}_{2} \mathrm{~g}$ dry wt leaf ${ }^{-1} \mathrm{~h}^{-1}$ at $31^{\circ} \mathrm{C}$ in September (Fig. 4). When compared to laboratory-derived values, a significant difference in gross $P_{\max }$ was found in late spring $(p=0.015)$, but not in late summer $(p=0.5$; Fig. 5a).

Respiration rates of photosynthetic tissue were 7 to 8 times higher than for non-photosynthetic tissues (Table 4). Calculations of whole-plant dark respiration based on tissuespecific $R_{d}$ and NPS:PS biomass ratios was higher in September than in May, at 74.5 and $55.9 \mu \mathrm{mol} \mathrm{O}_{2} \mathrm{~g}$ dry wt leaf ${ }^{-1} \mathrm{~h}^{-1}$, respectively. As mentioned previously, a second estimate of plant respiration based on chamber oxygen consumption per gram dry weight of leaf tissue within each chamber resulted in similar whole-plant respiration rates (Table 4), indicating that community respiration excluding seagrasses was negligible for the purposes of this study. Estimates of $R_{\mathrm{d}}$ derived from laboratory incubations of blade segments were 
Table 4. Thalassia testudinum. Dark respiration estimates based on (1) chambers in seagrass bed and (2) separate incubations of photosynthetic (PS) and non-photosynthetic (NPS) tissue at LLM. Chamber respiration was calculated as oxygen consumption within each chamber normalized to dry wt photosynthetic tissue. Whole plant $R_{d}$ represents the respiration supported by $1 \mathrm{gdw}$ ( $g$ dry wt) of PS material based on the relative biomass of non-photosynthetic and photosynthetic tissues (NPS:PS in gdw gdw ${ }^{-1}$ )

\begin{tabular}{|c|c|c|c|c|c|c|}
\hline & $\begin{array}{l}\text { Chamber respiration } \\
\left(\mu \mathrm{mol} \mathrm{O} \mathrm{O}_{2} \mathrm{gdw} \text { leaf }^{-1} \mathrm{~h}^{-1}\right)\end{array}$ & $\begin{array}{c}R_{\mathrm{d}} \mathrm{PS} \\
\left(\mu \mathrm{mol} \mathrm{O}_{2} \mathrm{gdw} w^{-1} \mathrm{~h}^{-1}\right)\end{array}$ & $\begin{array}{c}R_{\mathrm{d}} \mathrm{NPS} \\
\left(\mu \mathrm{mol} \mathrm{O} \mathrm{gdw}^{-1} \mathrm{~h}^{-1}\right)\end{array}$ & NPS:PS & $\begin{array}{c}\text { Whole-plant } R_{\mathrm{d}} \\
\left(\mu \mathrm{mol} \mathrm{O}_{2} \mathrm{gdw} \text { leaf }^{-1} \mathrm{~h}^{-1}\right)\end{array}$ & Net $P_{\max }: R_{d}$ \\
\hline May & $46.4 \pm 6.3$ & $26.0 \pm 2.5(\mathrm{n}=2)$ & $3.7 \pm 2.5(n=2)$ & 8.0 & $55.9 \pm 22.5$ & 1.2 \\
\hline Sep & $68.8 \pm 2.2$ & $34.7 \pm 0.2(\mathrm{n}=2)$ & $4.3 \pm 1.0(n=3)$ & 9.2 & $74.5 \pm 9.3$ & 1.6 \\
\hline
\end{tabular}

about 12 to $20 \%$ higher than whole-plant respiration rates (Fig. 5b). $P_{\text {net }}: R_{\mathrm{d}}$ ratios were 1.2 and 1.6 for May and September (Table 4)

Saturation irradiances were similar in May and September, averaging 297 and $281 \mu \mathrm{mol}$ photon $\mathrm{m}^{-2} \mathrm{~s}^{-1}$ for May and September, respectively. In situ estimates of $I_{\mathrm{k}}$ were over 3 -fold higher than those calculated from laboratory experiments; differences were highly significant $(p<0.001$; Fig. $5 c)$. Likewise, whole-plant compensation irradiances were over 3-fold higher than laboratory estimates (Fig. 5d). In situ estimates of relative quantum yield were $40 \%$ lower in May than September (Fig. 5e). Laboratory estimates significantly overestimated relative quantum yield ( $\mathrm{p}<0.001)$.

\section{Spherical and cosine PFD measurements}

During the $10 \mathrm{~d}$ period of sensor deployment at CCB there were no major storm or wind events, and hourly PFDs displayed similar trends (Fig. 6a). The spherical quantum sensor detected maximum daily PFD between ca 900 and $1000 \mu \mathrm{mol}$ photons $\mathrm{m}^{-2} \mathrm{~s}^{-1}$. The daily maximum for the sum of the 2 cosine sensors (i.e. light available for photosynthesis to both sides of a Thalassia testudinum blade) was between ca 400 and $500 \mu \mathrm{mol}$ photon $\mathrm{m}^{-2} \mathrm{~s}^{-1}$. Regression analysis indicated a strong correlation between the measurements of PFD made with spherical and cosine sensors $\left(\mathrm{r}^{2}=0.96\right.$; Fig. $\left.6 \mathrm{~b}\right)$; the sum of PFD for the 2 cosine sensors was approximately one half that measured with the spherical quantum sensor.

\section{Integrated and $H_{\text {sat }}$ production estimates}

Laboratory and in situ $P$ vs $I$ data for the late summer were used in conjunction with underwater PFDs during a $10 \mathrm{~d}$ period of high water clarity to generate production estimates. With the exception of results based on in situ

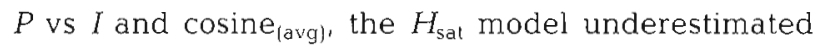
integrated production by about 10 to $15 \%$ for a given $P$ vs $I$ model and sensor (Table 5). The highest production estimates were obtained using the laboratory $P$ vs $I$ curve and spherical sensor PFDs; production was about $25 \%$ higher than for the combination of in situ $P$ vs $I$ data and spherical sensor PFDs as well as laboratory $P$ vs $I$ data and cosine $e_{(\text {avg) }}$. As expected, due to the low PFD values associated with cosine (avg) and high saturation irradiance of the in situ $P$ vs $I$ curve, these
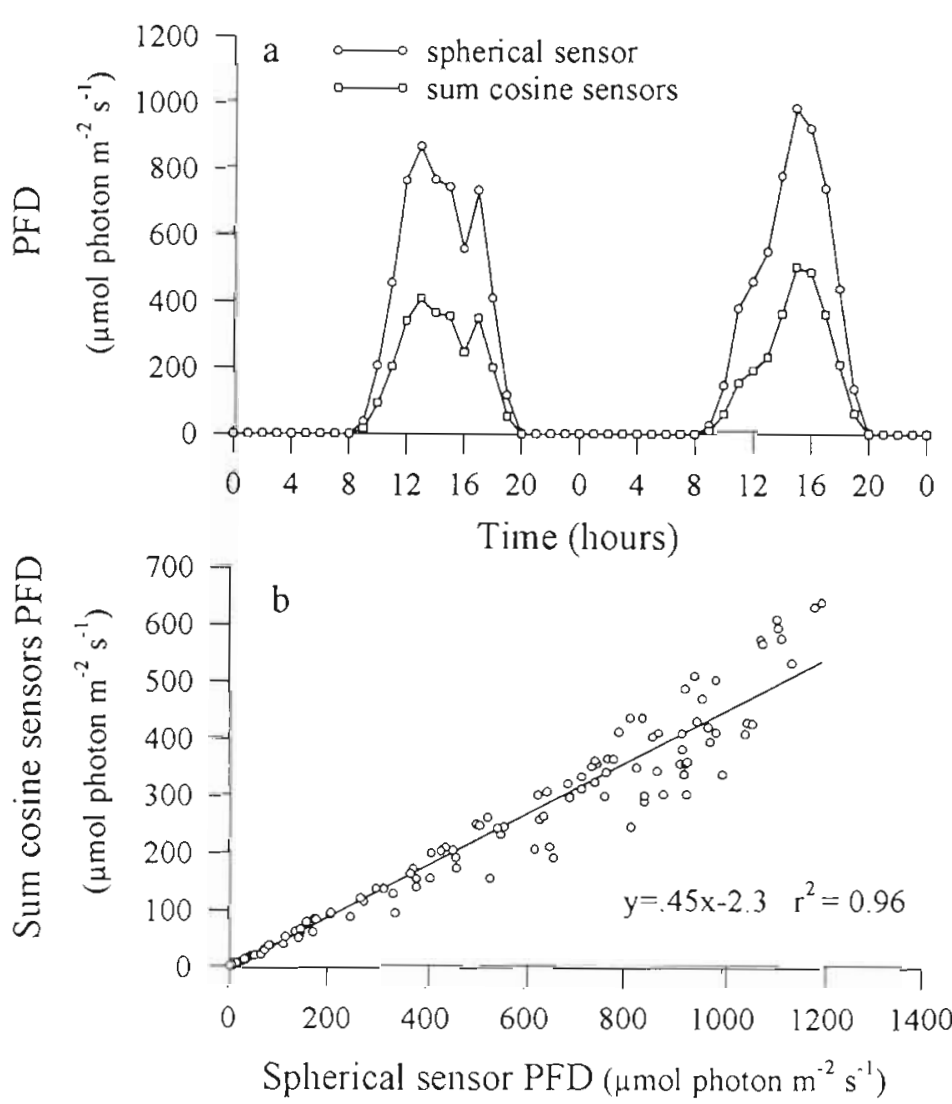

Fig. 6. (a) Simultaneous measurements of underwater PFD made with a spherical and 2 cosine sensors for a $10 \mathrm{~d}$ period in January 1996. The first $2 \mathrm{~d}$ of data are shown; the remaining days displayed very similar patterns. (b) Regression analysis between measurements made with a spherical sensor and the sum of the 2 cosine sensors 
Table 5. Thalassia testudinum. Mean \pm SE daily integrated and $H_{\text {sat }}$ production (values given in $\mathrm{mg} \mathrm{C} \mathrm{g} \mathrm{dry} \mathrm{wt} \mathrm{leaf} \mathrm{f}^{-1} \mathrm{~d}^{-1}$ ) calculated through use of laboratory (blade segments) and in situ P vs I (whole plant) curves for August and September 1995, respectively, in combination with continuous measurements of underwater PFDs made with spherical and cosine sensors during a $10 \mathrm{~d}$ period of relatively high water transparency. Numbers in parentheses represent daily period of light saturation in hours. A photosynthetic quotient of unity was assumed

\begin{tabular}{|llccc|}
\hline Sensor & \multicolumn{5}{c|}{ Pvs I model applied: } \\
& $\begin{array}{l}\text { Integrated production } \\
\text { Laboratory }\end{array} I_{\text {In } \text { situ }}$ & Laboratory & $H_{\text {sat }}$ production \\
& $I_{\mathrm{k}}=87$ & $I_{\mathrm{k}}=281$ & $I_{\mathrm{k}}=87$ & $I_{\mathrm{k}}=281$ \\
\hline Cosine & & & \\
Spherical & $19.1 \pm 0.53$ & $11.6 \pm 0.7$ & $17.5 \pm 0.9(7.0)$ & $1.6 \pm 1.0(1)$ \\
& $25.3 \pm 0.3$ & $21.7 \pm 0.4$ & $24.0 \pm 0.8(9.6)$ & $18.7 \pm 0.6(8.0)$ \\
\hline
\end{tabular}

study, the LLM site received greater integrated underwater PFD than $\mathrm{CCB}$ during the April through October summer period. Underwater light at the LLM site also exhibited a more predictable seasonal pattern and wider range in average daily PFD on a monthly basis ( 4 to $27 \mathrm{~mol}$ photon $\mathrm{m}^{-2}$ ) than CCB (8 to $17 \mathrm{~mol}$ photon $\mathrm{m}^{-2}$; Fig. 2). Greater average water column chlorophyll values at CCB (exclusive of brown tide; Table 1) and the presence of brown tide at LLM during the winter periods are 2 factors that contributed to differences in monthly and annual PFDs.

values drastically underestimate production. Since production is not typically calculated in this fashion, it will not be discussed further.

\section{DISCUSSION}

\section{Seasonal variations in $p$ vs $I$ parameters}

Seagrasses inhabiting estuarine systems are subject to biotic and abiotic factors that may be highly sitespecific. Evaluation of photosynthetic performance during a single time period by exposing plants to a temperature range reflective of the natural environment can provide information regarding the limits of physiological temperature tolerance, the optimum temperature for photosynthesis, effects of temperature on photosynthetic parameters and the interaction between varying light and temperature regimes (Bulthuis 1983, Pérez \& Romero 1992, Massini et al. 1995). However, this approach disregards natural variation in seasonal characteristics such as blade chlorophyll content and chl $a: b$ ratios, acclimation and the potential presence of internal annual. rhythms (Ott 1979, Wiginton \& McMillan 1979). Therefore, the characterization of $P$ vs $I$ parameters on a seasonal basis under a temperature regime reflective of in situ conditions provides a more meaningful representation of trends in photosynthetic performance (Drew 1978 , 1979. Pirc 1986, Dennison 1987, Dunton \& Tomasko 1994). In this study, the photosynthetic performance of 2 distinct populations of Thalassia testudinum in the western Gulf of Mexico was examined during 7 distinct seasonal periods between November 1994 and December 1995 as a function of underwater PFD, in situ temperature and blade chlorophyll content.

Underwater light can be highly estuary- and sitespecific, as reported by Zimmerman et al. (1991) for Zostera marina L. beds in San Francisco Bay and Dunton (1994) for Halodule wrightii in 3 Texas estuaries. In this
Laboratory incubations of blade material at temperatures reflective of in situ conditions indicated distinct seasonal trends in photosynthetic parameters; gross $P_{\max ,} P_{\max \text { chly, }} R_{\mathrm{d}}, \alpha, I_{\mathrm{k}}$ and $I_{\mathrm{c}}$ were iowest in winter, increased with higher water column temperatures in the early spring and peaked in the spring or summer months. In a seasonal study of photosynthetic performance of Cymodocea nodosa (Ucria) Aschers. in Spain, Pérez \& Romero (1992) found higher $P_{\max }$ and $I_{\mathrm{k}}$ values in summer than in winter. Other studies have also examined seasonal patterns in photosynthetic performance (Drew 1978, Libes 1986, Pirc 1986). Regression. analysis of $P_{\max }$ and $R_{\mathrm{d}}$ vs temperature indicated a correlation with in situ temperature $\left(\mathrm{r}^{2}=0.64\right.$ and 0.80 , respectively). The dependence of $P_{\max }$ and $R_{\mathrm{d}}$ on temperature has been reported previously in the seagrass literature (see Bulthuis 1983, 1987 for review).

Annual peak values of gross $P_{\text {max }} R_{\mathrm{d}}$ and $I_{\mathrm{k}}$ at CCB appear to lag LLM by about 2 mo; maximum values for LLM were detected in the early spring (April) and in summer (July/August) for the CCB population. The LLM station is located about $200 \mathrm{~km}$ southwest of CCB, therefore subtle differences in water column temperature, nutrient availability, daily light period or underwater PFD may trigger the annual peaks in maximum photosynthetic rates at different times at each station, which may be in turn associated with the maximal growth period. Drew (1978) found higher gross photosynthetic rates in spring at $17^{\circ} \mathrm{C}$ than in summer at $25^{\circ} \mathrm{C}$ for Posidonia oceanica (L.) Delile in Malta, while Cymodocea nodosa displayed the opposite pattern. The data presented here supports the hypothesis that accurate characterization of photosynthetic performance and determination of light requirements demands site-specific measurements

Photosynthetic parameter values reported in this study are within the range of those reported in the literature for Thalassia testudinum in Florida, Texas and Cuba for both laboratory and in situ measurements of $P$ vs $I$ (Table 6). At incubation temperatures 
Table 6. Thalassia testudinum. Photosynthesis versus irradiance parameters. Units for the relative quantum yield $(\alpha)$ are $\mu$ mol $\mathrm{O}_{2}$ $\mathrm{gdw}^{-1} \mathrm{~h}^{-1}$ ( $\mathrm{mmol}$ photon $\left.\mathrm{m}^{-2} \mathrm{~s}^{-1}\right)^{-1}$ The maximum rate of photosynthesis is presented in terms of gross values unless noted otherwise. For Dawes \& Tomasko (1988) and Fourqurean \& Zieman (1991) all data for each parameter were pooled. All conversions assumed a photosynthetic quotient of unity. nps: non-photosynthetic tissue $e_{i}$ : whole plant

\begin{tabular}{|c|c|c|c|c|c|c|c|c|c|}
\hline & $\begin{array}{l}\text { Temp } \\
\left({ }^{\circ} \mathrm{C}\right)\end{array}$ & $\begin{array}{c}P_{\max } \\
\left(\mu \operatorname{mol~O} \mathrm{O}_{2} \mathrm{gd}\right.\end{array}$ & $\begin{array}{c}R_{\mathrm{d}} \\
\left.\mathrm{d} w^{-1} \mathrm{~h}^{-1}\right)\end{array}$ & $\alpha$ & $\begin{array}{c}I_{k} \\
\text { (pmol pho }\end{array}$ & $\begin{array}{l}I_{c} \\
\left.\mathrm{~m}^{-2} \mathrm{~s}^{-1}\right)\end{array}$ & Method & Sensor & Source \\
\hline \multicolumn{10}{|c|}{ Blade segment incubations } \\
\hline $\mathrm{CCB}, \mathrm{TX}$ & 31 & 270 & 106 & 2.45 & 110 & 44 & $\mathrm{O}_{2}$ evol & $2 \pi$ & This study \\
\hline LLM, TX & & 208 & 85 & 2.44 & 87 & 36 & & & (late summer) \\
\hline $\mathrm{CCB}, \mathrm{TX}$ & 30 & 255 & 62 & 4.3 & 84 & nd & $\mathrm{O}_{2}$ evol. & $2 \pi$ & Czerny (1994) \\
\hline Lassing Park, FL & 26 & 94 (net) & nd & nd & nd & nd & $\mathrm{O}_{2}$ evol. & $2 \pi$ & Koch (1994) \\
\hline West Central Florida & la 30 & 231 & 78 & 2.6 & 62 & 35 & $\mathrm{O}_{2}$ evol & $2 \pi$ & $\begin{array}{l}\text { Dawes \& Tomasko } \\
\text { (1988) }\end{array}$ \\
\hline Cuba & 27 & 235 & 134 & nd & nd & nd & ${ }^{14} \mathrm{C}$ & nd & Buesa (1974) \\
\hline \multicolumn{10}{|c|}{ Whole shoot/whole plant incubations } \\
\hline LLM, TX & 31 & 195 & $\begin{array}{l}35 \text { leaf } \\
4.3 \mathrm{nps} \\
7.3 \mathrm{wp}\end{array}$ & 0.7 & 281 & 107 & $\begin{array}{l}\text { In situ } \\
\text { whole } \\
\text { plants }\end{array}$ & $4 \pi$ & $\begin{array}{l}\text { This study } \\
\text { (late summer) }\end{array}$ \\
\hline Florida Bay, FL & $25-30$ & 375 & $\begin{array}{l}14 \text { leaf } \\
3.3 \mathrm{nps} \\
4.9 \mathrm{wp}\end{array}$ & 0.9 & 407 & nd & $\begin{array}{l}\text { Lab. whole } \\
\text { shoots; } \\
\mathrm{O}_{2} \text { evol. }\end{array}$ & $2 \pi$ & $\begin{array}{l}\text { Fourqurean \& } \\
\text { Zieman (1991) }\end{array}$ \\
\hline $\begin{array}{l}\text { Redfish Bay, TX } \\
\text { Puerto Rico }\end{array}$ & $27-35$ & $\begin{array}{l}122 \text { (net) } \\
273 \text { (net) }\end{array}$ & $\begin{array}{l}\text { nd } \\
\text { nd }\end{array}$ & nd & $\begin{array}{l}250 \\
190\end{array}$ & $\begin{array}{l}\text { nd } \\
\text { nd }\end{array}$ & $\begin{array}{l}\text { Lab. }{ }^{19} \mathrm{C} \\
\text { fixation }\end{array}$ & $\begin{array}{l}\text { Pyrhelio- } \\
\text { meter }\end{array}$ & $\begin{array}{l}\text { Williams \& McRoy } \\
(1982)\end{array}$ \\
\hline Florida & -30 & 60.5 (net) & nd & nd & nd & nd & In situ ${ }^{14} \mathrm{C}$ & $\begin{array}{l}\text { Pyrano- } \\
\text { graph }\end{array}$ & $\begin{array}{l}\text { Bittaker \& lverson } \\
(1976)\end{array}$ \\
\hline
\end{tabular}

between 25 and $30^{\circ} \mathrm{C}$, gross $P_{\max }$ ranges between ca 200 and $375 \mu \mathrm{mol} \mathrm{O} \mathrm{O}_{2} \mathrm{~g}$ dry $\mathrm{wt}^{-1} \mathrm{~h}^{-1}$, while dark respiration rates for blade tissues range between ca 80 and $105 \mu \mathrm{mol} \mathrm{O}_{2} \mathrm{~g}$ dry $w^{-1} \mathrm{~h}^{-1}$. During low temperature periods $\left(<18^{\circ} \mathrm{C}\right)$ maximum photosynthetic and dark respiration rates may be up to one-sixth of the rates found during spring and summer for blade tissue (Czerny 1994, this study).

Since Thalassia testudinum displays higher light and respiratory requirements when in situ temperatures are high, anthropogenic activities that reduce water clarity should be avoided during these periods. Onuf (1994) associated seagrass loss in the Laguna Madre with maintenance dredging of the Gulf Intracoastal Waterway and suggested that reduced light availability was detectable as far as $1.2 \mathrm{~km}$ from dredged sites. Due to the high light requirements of $T$. testudinum during the spring and summer, dredging may have serious impacts on seagrass populations over large areas

\section{Blade-segment compared to whole-plant $P$ vs $I$}

The maximum rate of photosynthesis was not significantly different between whole-plant and laboratorybased estimates in late summer; however, significant differences were found for the late spring comparison. On the other hand, no significant differences were found in blade or whole-plant dark respiration rates. While laboratory incubations of blade segments do not include the respiratory requirements of non-photosynthetic tissue (Caffrey \& Kemp 1991, Fourqurean \& Zieman 1991, Table 4), gross production can be overestimated due to wounding effects which increase respiration rates. The lack of a significant difference between the 2 approaches may be due to an overestimation of $R_{\mathrm{d}}$ based on cut blade segments.

Relative quantum yield values from in situ incubations were approximately 5 -fold lower than $\alpha$ derived from blade segment incubations. Additionally, laboratory experiments tended to severely underestimate $I_{k}$; in situ measurements were 3 times higher. In a direct comparison of in situ and laboratory-derived photosynthetic parameters for Halodule wrightii, Dunton \& Tomasko (1994) found similar results. Likewise, Fourqurean \& Zieman (1991) reported high $I_{\mathrm{k}}$ and low $\alpha$ values for Thalassia testudinum in Florida (Table 6); their experimental setup simulated a seagrass canopy by incubating various shoots within chambers. High values of $I_{k}$ and low relative quantum yields based on shoot and whole-plant incubations have been reported previously for $T$. testudinum (Williams \& McRoy 1982 , Fourqurean \& Zieman 1991), Zostera marina (Wetzel 
\& Penhale 1983), Cymodocea nodosa (Pérez \& Romero 1992) and H. wrightij (Dunton \& Tomasko 1994).

Within a lush seagrass canopy, epiphyte cover and self-shading can drastically affect the light available for photosynthesis (Short 1980, Pérez \& Romero 1992, Massini et al. 1995). Tomasko (1992) found that Halodule wrightii increased rhizome growth and shoot formation rates when surface PFD was decreased using a 'canopy' of Thalassia testudinum blades as opposed to neutral density screening. The response was attributed to differences in spectral composition caused by seagrass shading. Consequently, selfshading will not only decrease light availability, but will also result in differences in spectral composition of light throughout the canopy. Therefore, estimates of $\alpha$ and $I_{k}$ derived from incubations of $T$. testudinum blade segments with a unidirectional light source are not reflective of the natural environment found within a seagrass canopy. Extrapolation from the laboratory to the natural environment should be exercised with caution, particularly when calculating daily periods of saturation $\left(H_{\mathrm{sut}}\right)$ or setting minimum light requirements.

\section{Spherical and cosine sensors: integrated production estimates}

Estuarine underwater PFD is usually measured with a spherical quantum sensor due to the diffuse nature of the light field (Kirk 1994) Gallegos (1993) suggested that biological considerations should determine whether spherical $(4 \pi)$ or flat cosine sensors $(2 \pi)$ are appropriate for monitoring underwater PFD in seagrass meadows. He suggested a spherical sensor should be used in the case of a solitary seagrass shoot exposed to a diffuse light field (such as that found toward the edge of a bed), while a flat sensor is suitable for an emerging shoot that can be viewed as a 'flat surface'.

Integrated production estimates based on spherical and $\operatorname{cosine}_{\text {|avgl }}$ sensor derived PFDs combined with summer in situ and laboratory-based $P$ vs $I$ data, respectively, were in agreement with each other (19 and $25 \mathrm{mg} \mathrm{C} \mathrm{g}$ dry wt leaf $\mathrm{f}^{-1} \mathrm{~d}^{-1}$; Table 5). Estimates of gross production within this range result in leaf growth rates of about $1.2 \mathrm{~g}$ dry wt $\mathrm{m}^{-2} \mathrm{~d}^{-1}$ (Herzka 1996, J E. Kaldy unpubl data) when whole-plant respiration is taken into account. However, integrated production estimates based on laboratory $P$ vs $I$ data and spherical sensor PFD measurements tended to overestimate production by ca $25 \%$. Estimates of production based on the $H_{5, i t}$ model displayed a similar trend, although production estimates were about 10 to $15 \%$ lower than integrated production for the $10 \mathrm{~d}$ period of favorable water clarity (Table 5). Since $P_{\max }$ derived from blade and whole-plant incubations was not significantly different for the September $P$ vs $I$ data utilized, differences in integrated and $H_{\text {sat }}$ production are attributed to the lower relative quantum yield 10.70

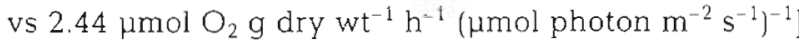
and higher saturation irradiance (281 vs $87 \mu \mathrm{mol}$ photon $\mathrm{m}^{-2} \mathrm{~s}^{-1}$ ) of in situ versus laboratory data, respectively.

Differences in production estimates derived through numerical integration or the $H_{\text {sal }}$ model should be greater during extended periods of low water transparency, when PFD $<I_{k}$. In order to test this hypothesis, a $10 \mathrm{~d}$ period of low water clarity recorded at the CCB station (28 October through 6 November 1995) was chosen to model production. During this time period, underwater PFD at CCB did not exceed $175 \mu \mathrm{mol}$ photon $\mathrm{m}^{-2} \mathrm{~s}^{-1}$ during any one day as a result of northern fronts leading to overcast skies and sediment resuspension.

Cosine $_{(\text {avg) }}$ was calculated as:

$$
\text { Cosine }_{\text {(avg) }}=\frac{\mathrm{PFD}_{\text {(sphericai }} \times 0.45}{2}
$$

where 0.45 is the slope of the equation derived from regression analysis of PFD measured with a spherical and sum of 2 cosine sensors in January 1996 (Fig, 6b).

Integrated production based on laboratory $P$ vs $I$ data combined with spherical sensor PFD measurements were 2.5 times higher than production calculated using in situ $P$ vs $I$ data (Table 7 ). Production based on cosine $_{(a v g)}$ and the laboratory $P$ vs $I$ data was $22 \%$ lower than estimates based on in situ $P$ vs $I$ data and PFD measured with the spherical sensor. The general pattern agrees with the estimates of production based on the period of high water clarity (Table 5), although the overestimation of production resulting from the combination of laboratory $P$ vs $I$ data with scalar PFD was much more drastic during the low water transparency period. Due to the intrinsic assumption of the $H_{\text {sat }}$ model, which states that production $=0$ when PFD $<I_{k}$, production under conditions of limited light

Table 7. Thalassia testudinum. Mean \pm SE daily integrated and $H_{\text {sat }}$ production (valves given in $\mathrm{mg} \mathrm{C}$ dry wt leaf : $\mathrm{d}^{-1}$ ) calculated for a $10 \mathrm{~d}$ period of low water transparency at $C \mathrm{CB}$. Numbers in parentheses represent the dally light saturation period in hours. A photosynthetıc quotient of 1.0 was assumed

\begin{tabular}{|lcccc|}
\hline Sensor & \multicolumn{5}{c|}{ Pvs $I$ model applied: } \\
& $\begin{array}{c}\text { Integrated production } \\
\text { Laboratory } \\
I_{\mathrm{k}}=87\end{array}$ & $I_{\mathrm{k}}=281$ & $H_{\text {sat }}$ production \\
& & Laboratory & In situ \\
$I_{\mathrm{k}}=87$ & $I_{\mathrm{k}}=281$ \\
\hline Cosine & $3.8 \pm 0.6$ & $1.1 \pm 0.2$ & $0.0(0)$ & $0.0(0)$ \\
Spherical & $12.1 \pm 1.5$ & $4.9 \pm 0.82$ & $7.2 \pm 21(2.9)$ & $0.0(0)$ \\
\hline
\end{tabular}


availability may be severely underestimated (Fourqurean \& Zieman 1991, Zimmerman et al. 1994). Hence, production calculated based on the $H_{\text {sat }}$ model and $10 \mathrm{~d}$ period of low PFDs severely underestimated integrated production. The model clearly fails for estuarine systems with variable (i.e. non-sinusoidal) or low-light regimes.

In conclusion, underwater light availability for seagrass maintenance and growth is site-specific, and should be monitored continuously to provide an accurate representation of the underwater light environment. Although blade incubations of Thalassia testudinum in the laboratory can provide useful physiological information regarding seasonal patterns in photosynthetic performance, laboratory estimates of $I_{k}$ based on blade segments may significantly underestimate light requirements, particularly if applied to PFD measurements made with spherical quantum sensors. Therefore, erroneous predictions of depth limits and seagrass productivity may result. Combining laboratory $P$ vs $I$ data with cosine $e_{\text {avgl }}$ sensor light measurements can underestimate production compared to estimates based on whole-plant $P$ vs $I$ and spherical PFD measurements by about $10 \%$ during periods of high water clarity and $25 \%$ during periods of low light. The results of this study support the importance of 'whole-plant' studies of plant metabolism and in situ light measurements.

Acknowledgements. We thank $J$ E. Kaldy and K.-S. Lee for extensive help in the field and laboratory. K. M. Major, S. V. Schönberg, K. R. Jackson, J. Kowalski and C. Weilhoefer were very helpful with various aspects of this work. C. A. Brown from Texas A\&M-Corpus Christi Conrad Blucher Institute provided continuous temperature measurements taken near both study sites. This research also benefited from conversations with R. C. Zimmerman, E. D. Ingall, C. A. Suttle and P. A. Montagna, as well as the helpful and constructive comments of $W$. J. Henley and 3 anonymous reviewers, to whom we are very grateful. This work was supported by the Texas Higher Education Board Advanced Technology Program (Grant No. 003658-419). This is contribution No. 1008 of The University of Texas at Austin Marine Science Institute.

\section{LITERATURE CITED}

Backman TW, Barilotti DC (1976) Irradiance reduction: effects on standing crop of the eelgrass Zostera marina in a coastal lagoon. Mar Biol 34:33-40

Bannister TT (1979) Quantitative description of steady state, nutrient-saturated algal growth, including adaptation. Limnol Oceanogr 24:76-96

Batuick RA, Orth RJ, Moore KA, Dennıson WC, Stevenson JC, Staver LW, Carter V, Rybicki NB, Hickman RE, Kollar S, Bieber S, Heasley P (1992) Chesapeake Bay submerged aquatic vegetation habitat requirements and restoration targets: a technical synthesis. US Environmental Protection Agency, Annapolis, MD
Bittaker HF, Iverson RL (1976) Thalassia testudinum: a field comparison of measurement techniques. Mar Biol 37 : $39-46$

Buesa RJ (1974) Population and biological data on turtle grass (Thalassia testudinum Banks ex König) on the Northwestern Cuban Shelf Aquaculture 4:207-226

Bulthuis DA (1983) Effects of temperature on the photosynthesis-irradiance curve of the Australian seagrass, Heterozostera tasmanica. Mar Biol Lett 4:47-57

Bulthuis DA (1987) Effects of temperature on photosynthesis and growth of seagrasses. Aquat Bot 27:27-40

Caffrey $\lrcorner M$, Kemp WM (1991) Seasonal and spatial patterns of oxygen production, respiration and root-rhizome release in Potamogeton perfoliatus L. and Zostera marina L. Aquat Bot 40:109-128

Cambridge ML, Chiffings AW, Moore BL, McComb AJ (1986) The loss of seagrass in Cockburn Sound, Western Australia. II. Possible causes for seagrass decline. Aquat Bot 24:269-285

Cambridge ML, McComb AJ (1984) The loss of seagrasses in Cockburn Sound, Western Australia. 1. The time course and magnitude of seagrass decline in relation to industrial development. Aquat Bot 20:229-243

Czerny $A B$ (1994) Growth and photosynthetic responses of two subtropical seagrasses. Thalassia testudinum and Halodule wrightii to in situ manipulations of irradiance. MA thesis, University of Texas at Austin

Czerny AB, Dunton KH (1995) The effects of in situ light reduction on the growth of two subtropical seagrasses, Thalassia testudinum and Halodule wrightii. Estuaries 18(2): $418-427$

Dawes CJ, Tomasko DA (1988) Depth distribution of Thalassia testudinum in two meadows on the west coast of Florida: a difference in light availability. PSZN 1: Mar Ecol 9:123-130

Dennison WC (1987) Effects of light on seagrass photosynthesis, growth and depth distribution. Aquat Bot 27:15-26

Dennison WC, Alberte RS (1982) Photosynthetic responses of Zostera marina L. (eelgrass) to in situ manipulations of light intensity. Oecologia 55:137-144

Dennison WC, Alberte RS (1985) Role of daily light period in the depth distribution of Zostera marina (eelgrass). Mar Ecol Prog Ser 25:51-61

Dennison WC, Orth RJ, Moore KA, Stevenson C, Carter V, Kollar S, Bergstrom PW, Batuick RA (1993) Assessing water quality with submerged aquatic vegetation. BioScience 43(2):86-94

Drew EA (1978) Factors affecting photosynthesis and its seasonal variation in the seagrasses Cymodosea nodosa (Ucria) Aschers, and Posidonia oceanica (L.) Delile in the Mediterranean. J Exp Mar Biol Ecol 31:173-194

Drew EA (1979) Physiological aspects of primary production in seagrasses. Aquat Bot 7:139-150

Duarte CM (1991) Seagrass depth limits. Aquat Bot 40 363-377

Dunton KH (1994) Seasonal growth and biomass of the subtropical seagrass Halodule wrightii in relation to continuous measurements of underwater irradiance. Mar Biol 120:479-489

Dunton KH, Tomasko DA (1994) In situ photosynthesis in the seagrass Halodule wrightii in a hypersaline subtropical lagoon. Mar Ecol Prog Ser 107:281-293

Fourqurean JW, Zieman JC (1991) Photosynthesıs, resprration and whole plant carbon budget of the seagrass Thalassia testudinum. Mar Ecol Prog Ser 69:161-170

Frenette JJ, Demers S, Legendre L, Dodson J (1993) Lack of agreement among models for estimating photosynthetic parameters. Limnol Oceanogr 38(3):679-687 
Gallegos CL (1993) Theoretical considerations in the use of $2 \mathrm{Pi}$ or $4 \mathrm{Pi}$ sensors to measure underwater light penetration for monitoring seagrass habitat. In: Morris LJ, Tomasko DA (eds) Proceedings and conclusions of workshops on: submerged aqquatic vegetation initiative and photosynthetically active radiation. St Johns River Water Management District, Palatka, FL, p 149-158

Gallegos CL, Platt T (1981) Photosynthesis measurements on natural populations of phytoplankton: numerical analysis. In: Platt T (ed) Physiological bases for phytoplankton ecology. Can Bull Fish Aquat Sci 210:102-112

Giesen WBJT, van Katwijk MM, den Hartog C (1990) Eelgrass condition and turbidity in the Dutch Wadden Sea Aquat Bot 37:71-85

Goldsborough WJ, Kemp WM (1988) Light responses of a submersed macrophyte: implications for survival in turbid tidal waters. Ecology 69(6):1775-1786

Hanelt D, Huppertz K, Nultsch W (1993) Daily course of photosynthesis and photoinhibition in marine macroalgae investigated in the laboratory and field. Mar Ecol Prog Ser $97: 31-37$

Henley WJ (1993) Measurement and interpretation of photosynthetic light-response curves in the context of photoinhibition and diel changes. J Phycol 29:729-739

Herzka SZ (1996) Photosynthetic performance and carbon balance of the seagrass Thalassia testudinum in Texas MA thesis, University of Texas at Austin

Jassby AD, Platt T (1976) Mathematical formulation of the relationship between photosynthesis and light for phytoplankton. Limnol Oceanogr 21(4):540-547

Kemp WM, Murray L, Borum J, Sand-Jensen K (1987) Diel growth in the eelgrass Zostera marina. Mar Ecol Prog Ser $41: 79-86$

Kenworthy WJ, Haunert DE (1991) The light requirements of seagrasses: proceedings of a workshop to examine the capability of water quality criteria, standards and monitoring programs to protect seagrasses. NOAA Technical Memorandum NMFS SEFC-287

Kirk JTO (1994) Light and photosynthesis in aquatic ecosys. tems, 2nd edn. Cambridge University Press, Cambridge

Koch EW (1994) Hydrodynamics, diffusion boundary layers and photosynthesis of the seagrass Thalassia testudinum and Cymodocea nodosa. Mar Biol 118:767-776

Kraemer GP, Alberte RS (1993) Age-related patterns of metabolism and biomass in subterranean tissues of Zostera marina (eelgrass). Mar Ecol Prog Ser 95:193-205

Lee KS, Dunton KH (1996) Abundance, production and carbon dynamics of the seagrass, Thalassia testudinum in Corpus Christi Bay, Texas. Nar Ecol Prog Ser 143:201-210

Lee KS, Dunton KH (1997) Effects of in situ light reduction on the maintenance, growth and partstioning of carbon resources in Thalassia testudinum. J Exp Mar Biol Ecol 210:53-73

Libes M (1986) Productivity-irradiance relationship of Posidonia oceanica and its epiphytes. Aquat Bot 26:285-306

Marsh JA, Dennison WC, Alberte RS (1986) Effects of temperature on photosynthesis and respiration in eelgrass (Zostera marina L.). J Exp Mar Biol Ecol 101:257-267

Massini RJ, Cary JL, Simpson CJ, McComb AJ (1995) Effects of light and temperature on the photosynthesis of temperate meadow-forming seagrasses in Western Australia. Aquat Bot 49:239-254

Mazella D, Mauzerall D, Alberte RS (1980) Photosynthetic light adaptation features of Zostera marina L. (eelgrass). Biol Bull 159:500

Morris LJ, Tomasko DA (1993) Proceedings and conclusions of workshops on: submerged aquatic vegetation initiative and photosynthetically active radiation. St Johns River Water Management District, Palatka, FL, p 149-158

Onuf CP (1994) Seagrasses, dredging and light in Laguna Madre, Texas, U.S.A. Estuar Coast Shelf Sci 39:75-91

Orth RJ, Moore KA (1983) An unprecedented decline in submerged aquatic vegetation. Science 222:51-53

Ott JA (1979) Persistence of a seasonal growth rhythm in Posidonia oceanica (L.) Delile under constant conditions of temperature and illumination. Mar Biol Lett 1:99-104

Parsons TR, Maita Y, Lalli CM (1984) A manual of chemical and biological methods for seawater analysis. Pergamon Press, New York

Pérez M, Romero J (1992) Photosynthetic response to light and temperature of the seagrass Cymodocea nodosa and the prediction of its seasonality. Aquat Bot 43:51-62

Pirc H (1986) Seasonal aspects of photosynthesis in Posidonia oceanica: influence of depth, temperature and light intensity. Aquat Bot 26:203-212

Porra RJ, Thompson W, Kriedemann PE (1989) Determination of accurate extinction coefficients with simultaneous equations for assaying chlorophyll $a$ and $b$ extracted with four different solvents: verification of the concentration of chlorophyll standards by atomic absorption spectroscopy. Biochim Biophys Acta 975:384-394

Prézelin BB (1992) Diel periodicity in phytoplankton productivity. Hydro 238:1-35

Pulich WM, White WA (1991) Decline of submerged vegetatuon in the Galveston Bay System: chronology and relationships to physical processes. J Coastal Res 7(4):1125-1138

Roberts DG, Moriarty DJW (1987) Lacunal gas discharge as a measure of productivity in the seagrasses Zostera capricorni, Cymodocea serrulata and Syringodium isoetifolium. Aquat Bot 28:143-160

Short FT (1980) A simulation model of the seagrass production system. In: Phillips RC, McRoy CP (eds) Handbook of seagrass biology: an ecosystem perspective. Garland STMP Press, New York, p 277-295

Smith EL (1936) Photosynthesis in relation to light and carbon dioxide. Proc Natl Acad Sci USA 22:504-511

Snedecor GW, Cochran WG (1989) Statistical methods. Iowa State Univ Press, Ames

Stockwell DA, Buskey EJ, Whitledge TE (1993) Studies on conditions conducive to the development and maintenace of a persistent 'brown tide' in Laguna Madre, Texas. In: Smayda TJ, Shimizu Y (eds) Toxic phytoplankton blooms in the sea. Elsevier Science Publishers, Amsterdam, p 693-698

Talling JF (1957) A new model for leaf photosynthesis incorporating gradients of light environment and the photosynthetic properties of chloroplasts within a leaf. Annls Bot 56:489-499

Tomasko DA (1992) Variation in the growth form of shoal grass (Halodule wrightii) due to changes in the spectral composition of light below a canopy of turtle grass (Thalassia testudinum). Esturaries 15:241-217

Vicente VP, Rivera JA (1982) Depth IImits of the seagrass Thalassia testudınum (Banks ex König) in Jobos and Guayanilla Bays, Puerto Rico. Caribb J Sci 17(1-4):73-79

Wetzel RL. Penhale PA (1983) Production ecology of seagrass communities in the lower Chesapeake Bay. Mar Technol Soc J 17(2):22-31

Wiginton JR, McMillan C (1979) Chlorophyll composition under controlled light conditions as related to the distribution of seagrasses in Texas and the US Virgin Islands. Aquat Bot 6.171-184

Williams SL, McRoy CP (1982) Seagrass productivity: the effect of light on carbon uptake. Aquat Bot 12:321-344 
Zimmerman RC, Cabello-Pasini AA, Alberte RS (1994) Modeling daily carbon gain of aquatic macrophytes from quantum flux measurements: a comparative analysis. Mar Ecol Prog Ser 114:185-196

Zimmerman RC, Kohors DG, Steller DL, Alberte RS (1995) Carbon partitioning in eelgrass. Plant Physiol 108: $1665-1671$

This article was submitted to the editor
Zimmerman RC, Reguzzoni JL, Wyllie-Echeverria S, Josselyn M, Alberte RS (1991) Assessment of environmental suitability for growth of Zostera marina L (eelgrass) in San Francisco Bay. Aquat Bot 39:353-366

Zimmerman RC, Smith RD, Alberte RS (1989) Thermal acclimation and whole-plant carbon balance in Zostera marina L. (eelgrass). J Exp Mar Biol Ecol 130:93-109

Manuscript first received: October 29, 1996 Revised version accepted: April 7, 1997 